\title{
The Postdigital University: Do We Still Need Just a Little of That Human Touch?
}

\author{
Debra Cureton $^{1}$ (D) Jenni Jones ${ }^{2} \cdot$ Julie Hughes $^{3}$
}

Accepted: 16 November 2020 / Published online: 21 December 2020

(C) Springer Nature Switzerland AG 2020

\begin{abstract}
An increasing body of literature considers the role of belonging and social connectivity in undergraduate student success. The core tenet of this research is that relationships are crucial to the development of a sense of belonging. However, within the Higher Education (HE) sector, our processes, and therefore how we interact with students, are becoming more and more automated. None more so than during the Covid-19 pandemic and the 'new normal' in HE. This paper considers how we, as a profession, might support each student's developing sense of belonging within a sector that is shifting towards increased digitalisation. This is achieved through considering the political agenda that drives the creation of digital education and some of the assumptions that underpin the movement towards it. As a result, a theoretical platform is created to consider the areas where digitisation impacts on teaching staff, and on students, and how this relates to each student's sense of belonging within HE. The inclusion of two case studies has provided the opportunity to answer two key questions: (1) What is important to students developing a personal sense of belonging in $\mathrm{HE}$ during their first few weeks in a university? (2) How can the differentiated human touch be provided by 'third space' professionals both in person and virtually?
\end{abstract}

Keywords Student belonging $\cdot$ Digital $\cdot$ Postdigital university $\cdot$ GTA $\cdot$ Academic coaches

\section{Context}

A sense of belonging in an educational setting refers to how connected a student is. This includes the social connections a student has with friends, peers, lecturers and

Debra Cureton

d.cureton@wlv.ac.uk

1 University of Wolverhampton City Campus, Wolverhampton, West Midlands, UK

2 University of Wolverhampton Business School, Wolverhampton, UK

3 University of Wolverhampton, Wolverhampton, UK 
university staff, as well as a psychological sense of closeness, which leads to feelings of 'personally being accepted, respected, included and supported' (Goodenow 1993: 80). Many students have likened this to feeling that they are 'are part of the family' (Cureton 2017; Cureton and Gravestock 2019). Therefore, having a sense of belonging would appear to be an important factor in supporting a student's chances of academic success. A sense of belonging and student's academic success have been linked in a number of studies (Cousin and Cureton 2012; Thomas 2012; Thomas et al. 2017), as well as being identified as a factor in attainment gaps when it is lacking (Mountford-Zimdars et al. 2015). Explanations for this include that peer relationships can normalise difficult academic experiences (Cureton and Gravestock 2019) and provide a network with which to explore things that students do not always understand such as assignment briefs (Cousin and Cureton 2012). Additionally, belonging can help students to navigate transitions into and through university (Cureton and Gravestock 2019) and help students develop academic resilience (Cureton 2017), to name but a few.

To consider the role of belonging and student success in the postdigital university, it is first necessary to set the scene by reflecting on what postdigital means in the current political landscape and its impact on the HE sector. In particular, it is crucial to consider what the drivers are for the creation of 'the digital University' and who ultimately benefits, before considering how this affects student belonging, and through this, may impact upon student retention and success.

\section{The Shifting Higher Education Landscape-The Driving Force Behind the Corporatised University}

The HE landscape is constantly shifting. As always, these changes are multi-layered with the impact felt at two levels of the educational ecosystem (Bronfenbrenner 1979); these are the microsystem (e.g. the student) and the mesosystem (e.g. lecturers, academic developers, the university). Sector change is led by the exosystem (e.g. the sector agencies such as the Office for Students) and the macrosystem (e.g. The Government and Department for Education). When considering the current HE context in the UK, we are negotiating sector changes that include the ramifications of a looming Research Excellence Framework assessment (REF) in 2021, the introduction of the Teaching Excellence Framework (TEF) (GovUK 2017a) and the impending implementation of the Knowledge Exchange Framework (KEF) later in 2020 (UKRI 2019).

The introduction of the frameworks above has generated a metrification of the university sector (Williamson 2017). Whilst metrics in HE are not new, the Higher Education Act 2017 (GovUK 2017b) has intensified this, and suggests that university outputs, students' experiences and lecturers' skills are numerically measurable. In addition, this could also create a 'narrow and instrumental view of education' (Fawns et al. 2020: 1). Increasingly, universities are creating and becoming data intensive mechanisms in order for sector-wide comparisons to be made (Williamson 2017). In addition to the metrification of $\mathrm{HE}$, there are changes within the funding of degrees that have challenged the traditional operationalisation model utilised in the sector. In particular, the funding of degrees, such as teacher and nursing education, has required significant strategic change in the way that universities deliver education in these areas, in order for them to access the relevant funding. 
Moreover, linking the ways that Universities are funded to their TEF results aims to increase teaching excellence (Gunn 2018) despite there being no clear definition of what constitutes teaching excellence (Warnes 2020), or any evidence that recognition of teaching excellence impacts on the overall quality of learning and teaching in Universities (Warnes 2020). However, the link has tempted Universities to behave more purposefully, especially in relation to areas that concern students' experiences that are measured in the TEF (Spence 2019). Here, it is worth noting that Ball (2017: 8) urges us to enter into policy debate, such as the imposition of the TEF, and to play a key role in the 'discursive struggle and ...re-narration' of the public sector.

Consequently, 'modern universities have become big businesses' (Bosetti and Walker 2009: 16) and as such we are witnessing a shift to a more business or corporatised model of HE (Corver 2019). This move towards corporatisation has implications for how the sector views knowledge (Van der Zwaan 2018). The corporatised model of HE is more likely to try and deliver what the economy needs rather than what each learner desires. Nevertheless, the majority of people who are currently receiving a higher education, will ultimately enter jobs that currently do not exist (World Economic Forum 2018).

Consequently, not only are universities striving to provide what the sector needs, they are predicting what the sector might need in our postdigital future in order to deliver the right transferable knowledge and skills set to its students. The consequence of this corporatised model is that it could fail to get future planning right and we could end up by not providing what the economy needs either. Here we can draw on the example of the current economic crisis that has arisen due to Covid-19. Universities could not have predicted that in 2020 the country would be involved in a nation-wide lockdown, and that as a result, the stability of many businesses would be threatened. The unemployment rate for June to August 2020 was $4.5 \%$ and indicates an increase of $0.4 \%$, which in real terms equates to there now being 1.5 million people who were unemployed (Office for National Statistics 2020).

Many people, who once considered themselves to be in a stable occupation, now find themselves unemployed and facing the need to retrain. Many will look to HE to give them the 'edge' in the job market, but may find that whilst they are highly skilled professionally, their skills are not directly transferable to the academic setting. If you do not feel that you fit, how can you feel that you belong? We argue below that third space professionals are key to bridging this gap, in supporting new students to explore how their skills can be adapted to help them meet the standards of HE. However, we do need to consider the capacity issue pertaining to this provision. This should not be overlooked, especially as within the corporatised education system, the focus is not only about how universities support the acquisition of knowledge, but about how knowledge is managed, (Van der Zwaan 2018) developed and recorded, therefore intensifying the need to rely on metrics as the intelligence to do so.

The changing focus toward metrification and corporatisation in HE is further accentuated as a result of the Higher Education Act (2017) (GovUK 2017b). The Act implemented strategies to diversify the sector, and now offers degree awarding powers to the wider market of providers, in order to generate greater competition within the sector. As a result, there has been an expansion in the types of organisations who are allowed to hold the power to award degrees, and therefore administer the Student Loans that provide funding. This has led to a change in focus for some private HE providers 
within the UK, who have moved from their traditional focus on the delivery of vocational education, to providing a similar opportunity as the publicly funded universities (Hunt and Boliver 2019). This has been further fuelled by competition from private providers, an increased focus on what employers want, employability skills (Chartered Management Institute 2018) and rapid technological advances (Bolden et al. 2012), which have led to increased use of technology and innovative delivery methods (e.g. elearning).

This has opened up more international, offshore opportunities coupled with more international competition, and additional non-traditional HE qualification routes (e.g. apprenticeship programmes). Through this process, a growing number of digital universities, that offer an online or blended education, are making an appearance as UK HE providers. The enhanced competition aims to attract the decreasing UK population of 18-year-old students and the international student market, which the publicly funded universities require to survive in these difficult economic times. This and the shift of funding away from the government grant and tuition system to studentowned tuition fees, plus the lifting of student quota controls, has created an expansion in the HE system (Boxall 2016). This more competitive and diverse environment has led to changes within the landscape in which HE is provided, the support that is given, the way in which teaching and learning is delivered and the way in which Higher Education Institutions (HEIs) are being led and managed. Moreover, this has led to changes in the way in which students are supported and managed (Ashwin 2005; Brown 2013). An example of this is within teacher education. Funding for teacher education is no longer given directly to HE. Student bursaries for teacher training differ in amount and are dependent on the demand for new teachers in the discipline area. This has consequences for HE funding, which in turn impacts on the resources that Universities have to support student groups.

Since 2017, there has been rapid decline in the number of 18-year-olds that will not rectify itself until 2023 (Office for National Statistics 2018). This means that there are less traditional students looking to enter HE. There is also the potential that many of this group who wanted to enter into HE may have reduced due to the pandemic. Covid19 has caused many disruptions in the delivery of secondary and tertiary education, as well as in how HE is delivered. This has impacted students' choice of whether to enter into HE this year, or delay until next year, in the hope that next year's 'new normal' is more like last year's normal, than what we witness today. Add to this, the impact of the various ' $U$ turns' in how the A Level results were calculated for this year's 18-yearolds, and the number of students who may wish to re-sit their A Levels so that they are assessed on an actual examination, or have chosen to challenge what the A Level algorithm has indicated that their outcome should be and there is potential for intakes to be substantially reduced.

The introduction of the $£ 9000$ fees in 2012 (GovUK 2018) also negatively impacted on mature students' motivations to engage in HE, and a catastrophic $51 \%$ decline in mature learners has been witnessed (Callender and Thomson 2018). In response to this, universities are pressed to diversify in order to encourage entrants. In addition, cultural changes have impacted on the expectations that students have about the ways in which education is conveyed, and despite understanding that their education takes place in a massified environment (Cureton 2017), students expect a personalised education (Cureton 2017; van der Zwaan 2018). 
Given the view of the corporate university that is outlined above, it is hard to see how it puts the student at the centre of the educational experience, let alone how it presents a caring or nurturing environment that welcomes, embeds and supports students in their learning journey. It is evident that the corporate university is one in which the human touch is missing.

\section{So What Is a Digital University, Who Might It Benefit and How Is a Postdigital University Different?}

Understanding the HE landscape and changes within is central when considering what a postdigital perspective on student belonging might offer. Above, we have considered the driving factors in the development of a digital university, who these are led by and who are the beneficiaries. Now we consider how the postdigital university offers a different perspective and the role in offering 'that little bit of a human touch'. There is much debate about the definition of 'postdigital'; arguments proffered the definition of 'post' (Sinclair and Hayes 2019), the influence of using a hyphen (post-digital) (Jandrić et al. 2018), critiques of the impact of 'the digital' for education and research (Knox 2019) and the science and philosophy that underpins 'postdigital science' (Peters and Besley 2019). These are all considered and applied in the arguments below.

The digital university is a creation of the exosystems and macrosystems (the Government and its agencies) for the benefit of the microsystems and mesosystems (students, universities and their staff). It would also appear that the digital university is created in response to the demands of the exosystems and macrosystems and their desire to quantify the impacts of HE. On balance, we cannot ignore the lens that metrification places on the sector as a whole. Synonyms of digital, after all include numeric, numeral, ordinal and arithmetical, to name but a few. So, this lens may suggest that the digital university is one that focuses on, and is driven by, its metrics and this takes place at a 'business as normal' level. However, is this the end game?

The fact that digital focuses on metrics does not mean that the postdigital does the same. In fact, the postdigital university could be one that takes a more considered view of metrics, one which includes the aspects of teaching, learning and the educational context that are currently ignored in quality metrics. In doing so, measures of quality could enhance the voices of all stakeholders (students, lecturing staff, HEIs and players within the wider educational context) rather than reduce their experience to numbers. This would create a rich tapestry of data types, 'including non-datafied understandings' as evidence of teaching excellence that empower stakeholder agency (Fawns et al. 2020). To this end, the postdigital university could be a place where metrics are supported by expert judgement, and through which an environment is created that equally values and understands the role of technology and the pedagogue (Fawns et al. 2020).

Additional support is garnered for the data-driven university in that the sector practice now places a greater emphasis on learner analytics and their proposed ability to predict when a student needs help or is at risk of dropping out (Herodotou et al. 2019). Whilst the encouragement to utilise this initiative originated in the exosystem, it could also be argued that this puts the microsystem) (the student) in the central focus. Here, attention should be paid to the ways that this data is used to support the student. In the digital university, learner analytics are a form of ongoing surveillance (Arndt et al. 2019). Learner analytics generates data that is used in a deductive fashion and means that the 
student is seen as one of a group, who behaves like the group. The deductive use of data from Learner Analytics suggests that if $x$ is noted in the majority, $x$ is likely to occur for everyone within that group, and is therefore not only exacting control over students and their teachers (Arndt et al. 2019) but are defining the learning relationships that are critical to students' success.

These technologies are not new. Students have been aware of learner analytics throughout their education, and it is something that they are used to working with, but smaller classes and the opportunity for primary, secondary and tertiary level teachers to know their students, means that at these levels, students are less likely to be defined by their learner analytic profile. Looking at learner analytics through a postdigital lens encourages a nuanced view of how such technology are used within education by both student and teacher, and recognises that 'contemporary student practices with technology are complex entanglements between physical and digital technologies, spaces, activities, and time' (Jandrić et al. 2018: 896). Therefore, in the postdigital university, this type of data can be used to aid students' understanding of how HE works rather than for HE's understanding of how the student works. In short, it can encourage members of the university to interact with students; this is an idea that we will return to later in this overview and again in the case studies.

An alternative argument, offered above, is that the digital university is driven by the economic needs of the mesosystem through which a growth in digital education has been witnessed. An additional element of the definition of the digital university is one in which the educational experience is digitally delivered or has 'the digital' interwoven throughout. Changes in degree awarding power has led to an increase in digital universities. However, 'the digital' is never far away within the traditional university either, and has been very much at the forefront of HE activity during the Covid-19 pandemic.

This is found in two forms. Firstly, it is evident in learning, teaching and assessment activities. Secondly, it is utilised within the administrative aspects of the student lifecycle: such as in the application process, enrolling at university, registering for modules, submitting assessments, accessing grades and feedback from lecturers, applying for Mitigating Circumstances and Leaves of Absence, and enrolling for graduation. The former is an economic response to matching the offer of competitors and the latter was implemented to cut costs. No matter its original mission, the digitisation of the curriculum has been a costly endeavour (Brabazon 2011), as has the automisation of the wider administration of the learning experience. This investment suggests that there is no turning back; however, the postdigital university would posit that there is always room for improvement and that future digital streamlining provides an opportunity to enhance student experiences and the assessment of quality teaching (Fawns et al. 2020).

Over recent years, pedagogical developments have increasingly encouraged a focus on 'digital delivery' including digital pedagogies (Lewin and Lundie 2016), blended learning (Friesen 2012) and flipped learning (Baker 2000; Lage et al. 2000) approaches. This suggests that an additional, probably reluctant, drive for the digital university comes from those who design and who implement pedagogy, and thus this includes Academic Developers and lecturing staff. As curriculum and pedagogical advances are often underpinned by a university's learning, teaching and assessment (sub)strategies, the university is a partner in forwarding these approaches. All of these entities are 
located within the mesosystem and this suggests that the mesosystem is also involved in the creation of the digital university. At the heart of these changes are students' experiences, however, therefore, we question: is this how students want to experience their learning in HE?

This can be partly addressed through returning to a definition of 'the digital' vs 'the postdigital'. It is widely agreed that the digital is mainly located in physics, whereas the postdigital is located in the biological (Pepperell and Punt 2000). The postdigital offers the opportunity to focus on the human rather than machinery. Moreover, the postdigital perspective recognises the impact of technology on human psychology, and calls for more work to be carried out to understand the impact of the digital on inter-generational psychology, as well as highlighting a need to understand the development of digital identity (Arndt et al. 2019). However, these calls have yet to recognise that we need to develop an understanding of how the postdigital university might be the platform to bridge the gap between the digital interface and interpersonal connectivity, which is what this paper addresses.

A further argument is that the digital university is created through an interaction of the macrosystems, exosystems and mesosystems in order to benefit the microsystem. The sector has driven changes to who could award degrees, has facilitated the move towards an increased corporatisation in HE. This has created an institution that purposely focuses on the areas of business that most impacts on its metrics (Spence 2019). Although the changes in the types of institution that can hold degree-awarding powers may have encouraged the corporatisation of $\mathrm{HE}$, the arguments that underpin the expansion of degree-awarding powers focuses on a number of purported benefits to students. These include positively impacting on teaching standards, enhancing students' opportunities and therefore life chances and providing a catalyst for social mobility (Department for Business, Innovation and Skills 2016: 9). On the one-hand, this suggests that the drive for a digitalised university is to enhance the experience of the students (the microsystem), thus highlighting a 'protective' drive for the digital university from the exosystems and macrosystems, which pressures the macrosystem to generate more beneficial outputs for the microsystem. Yet, is this the reality; are students leaving university having had an 'enhanced' experience and leaving with greater opportunities, life chances and mobility? In answer to this, the postdigital perspective asks us to carefully consider how the complex fusions of analogue and digital technologies, and social practices (Jandrić et al. 2018) intermingle with the diversity of individual student experiences. At this point in history, we cannot just focus on one without the other.

Some may argue that the digital university is microsystem driven. Due to the lower numbers of 18-year-olds and the decline of mature learners due to the introduction of fees, there is a change in the constitution of the student body. The sector wide struggle to recruit HE learners has led to a greater focus being placed on diversifying the offer in order to reassure mature learners that $\mathrm{HE}$ is for them, and to attract lifelong learners into HE (Government Office for Science 2017). An inherent message within this is that flexibility is available within the learning arena. This, in turn has led to a demand for a customised educational approach, in which digital education is a key factor (Van der Zwaan 2018).

Younger students have become accustomed to personalised learning through their primary and secondary education (National College for School Leadership 2005) and digitalised learning environments (Williams 2008) and as a result, being able to adapt 
all of the technologies that they use in their everyday lives (Williamson 2017). So it is not a big leap to suspect that customised learning is desired by all ages of learner. However, are all students equally involved in the drive to create the digital university? To make the digital accessible is fundamental in the step from a digital focus to a postdigital environment. A digital university is only accessible to students if they have the digital capabilities that enable them to navigate the digital interface of the university. If the economic drive is to fill the void of 18 -year-olds with older students, it has to be recognised that not all HE students are 'digital natives' and many may be migrants who are at varying stages of their immigration (Prensky 2001). Even those who might be considered as 'digital natives' may well understand and want to use technology differently from the ways that HEIs utilise it (Dingli and Seychell 2015). The concept of digital natives is heavily contested for its naivety, yet (Bayne and Ross 2011; Guo et al. 2008) this again highlights the need for flexibility. The postdigital vision of HE is that it is accessible, developmental, and that technology offers flexibility and options for both student and educator.

The arguments presented in the first section of this paper suggest that it is sector changes and HE institutions' responses to these that is the driving force behind the growth of the digital university. The latter section suggests that to step outside the digital and consider the power of the postdigital university, HE institutions need to make friends with data, place pressure on the sector to include meaningful data in their evaluations of teaching excellence and through this to recognise and empower the students and their educators. Moreover, universities need to move beyond the physics of the digital and embrace biology alongside, by considering how educators and students embrace and use digital technology to enhance learning experiences.

This paper asks readers to take one further step, and to consider psychology within the postdigital university by considering how through technology we can facilitate the interpersonal, how we ensure connectivity with others and how student belonging is enacted and experienced within a postdigital context. The rest of this paper raises and answers two questions: (1) What is the role of technology in students' developing a sense of belonging? (2) How do third space professionals, those who are not traditional teachers but have been appointed in HE roles based on their expertise, with the aim of support and enhancing how students experience HE (Whitchurch 2013), use technology to provide the human touch?

Brown (2018) argues that changes in perceptions about how teaching and learning is delivered and received are leading institutions to consider the ways in which students are supported to enter higher education and engage with curriculum and assessment activity. Gale and Parker (2014) identified that the concept of transition at all stages of the student lifecycle was under-theorised, and the last 5 years has seen an expansion of the literature and sectoral activity in this area. O'Donnell et al. (2016) report for the Higher Education Academy problematises assumptions made about what transition is and how it is experienced by individuals. A growing body of authors, influenced and challenged by Gale and Parker's broad conceptualisation of transition as a period of induction, of development and as becoming are conceptualising, transitioning across the student lifecycle as a process through, towards and out (Matheson and Sutcliffe 2018) of HE.

O’Donnell, Kean, and Stevens (2016: 19) key findings from case studies in eight institutions in the UK emphasise the shifting nature of transitioning on individuals, 
relationships between students and staff and upon institutional contexts. Emphasis is placed upon the need for institutions to be reflexive about their practices and to gather, 'rigorous qualitative research into student experiences of development and change across the learning journey, which would complement quantitative evaluations of retention rates' (19). The authors urge the sector to adopt radically flexible approaches to accommodate diversity and diverse ways of knowing, thinking and doing. In doing so, we offer two case studies from within the same HE institution that support the argument that the digital aspects of students' HE experiences are less important to students, despite that as a result of the current HE landscape they are here to stay. If we want an environment where students' desire to belong is met, and through this to create an environment in which students will transition across the student lifecycle successfully (and satisfy the metrics craved by the digital university, Government and its agencies), understanding human interaction as an inherent aspect of postdigital interaction is core.

The case study organisation is a UK post-1992 HE institution which has traditionally attracted a diverse student body. It is an anchor institution for our region spanning 4 campuses and has 21,000 students studying annually. Seventy-five percent of our students commute to study from within a 25 -mile radius and $78 \%$ of our alumni live and work in the region. Sixty-eight percent of our students are the first in their family to study at university and $48 \%$ are mature entrants. A recent study found that $60 \%$ of our students rely on childcare whilst studying and $15 \%$ of students identify as carers. Fortyseven percent of students identify as Black, Asian, Minority, Ethnic students, and 19\% of students come from the lowest undergraduate participation areas. Within this complex student body, this university, not unusually for the sector, has experienced challenges with student recruitment, retention and completion rates for underrepresented groups. Simultaneously, the institution has seen an increase in applications for Foundation Year (FY) study with our current cohorts representing almost a quarter of our new on-campus entrants. In an era of unprecedented government and public accountability and scrutiny undertaking social justice, widening participation activity might be perceived as high-risk for this institution.

The first case study addresses the question of what is important to students' sense of belonging during their first few weeks at university. The second case study addresses the question of how a differentiated human touch can be provided by 'third space' professionals.

\section{Case Study One: Developing a Sense of Belonging}

This study was aimed at gaining a better understanding of our students in terms of their early university experiences from analysing 80 first-year student reflective essays which focussed on how they felt about their first semester and what most concerned them in the early part of their HE journey.

The research participants were all first-year students attending a business management-related undergraduate degree (UG). The work of $80 \mathrm{UG}$ students who had studied a core business management 20 credit module entitled 'Learning for Business Success' was chosen. All UG students were full time, first semester students. There were two reflective assessments for this module. As part of their first reflective 
essay (assessment 1), they were asked to reflect on their first 4 weeks at university. As part of their second reflective essay (assessment 2), they were asked to reflect on what has helped and hindered their HE journey so far. Only those essays that had reflections in both areas i.e. their first 4 weeks and factors that helped and hindered, were included in the empirical data set. The pass mark was not a determining factor. The characteristics of the students, e.g. gender, ethnicity, age, disability, social class and previous educational background were not taken into account; the effects of intersectionality for each student is certainly an area for future, more in-depth investigation. The key words that were expressed across the two sets of 80 reflective essays were selected, coded and collapsed into key themes. Common themes emerged for all students.

Overwhelmingly, the comments from these students about their first few weeks at university were negative (83\%). The majority of the students were 'worried about the challenge', the feeling of being 'pushed out of their comfort zone', together with worries about the 'big jump' from school/college to higher education study. Others discussed the feelings of being 'nervous', 'anxious' and 'lonely'. Only 17\% of these students reported feeling 'excited' and 'invigorated' by the idea of studying at university. Students shared the aspects they felt led to their negative feelings and for all students, there were huge concerns (listed in priority order) about making friends, understanding where they were going, the university processes, e.g. enrolling, accessing financial support and tutors.

Interestingly, making friends was the biggest concern (mentioned by half of the students), with some saying; 'I was worried about confronting new people and was nervous about making new friends' and 'When I first started university I personally found it very daunting, mainly due to the fact that I didn't know anyone'. These quotes show that initially they were worried and nervous about meeting and engaging with new and different people.

However, after a few weeks, the students stated they felt less worried and less daunted:

I was already able to notice through getting to know people how much difference there were between everyone studying in the business school from their different backgrounds and cultures... this gathered together pushed me to getting close to people with different cultures which I had never done before [and] Once I started to speak to new people and make new friends I realised university isn't as daunting as I once imagined... Immediately during the first weeks of university I think that I have begun to appreciate all kinds of people.

These quotes show that it did not take too long for these students to feel comfortable around new and different people. Both quotes mention 'getting to know people' and 'speak[ing] to new people' which clearly demonstrates the importance of human contact. All comments made about making friends after the first 4 weeks moved from negative to positive responses.

Also, over a third of the new students stated that they were concerned about finding their way and all the responses were negative in respect of buildings and space to start with: 'Dauntingly confusing campus.... the business campus is massive like a rabbit warren' and 'I had no idea where I was going or how the university operated'. Interestingly, daunting was a word used for both making friends and buildings. 
Initially, concerns seemed to be around the sheer size of the campus and buildings using words like 'massive' and 'big', and the 'potential for getting lost'. However, it did not take too long for these students to become comfortable with the surroundings, with some students after 4 weeks saying: 'Things quickly fell into place after I had discovered where my lectures and seminars where and who they were taught by, which buildings were which' and 'Fast forward to a few weeks after that day I've now settled in and familiarised myself with the different buildings.' In short, 4 weeks later, concerns about both friends and buildings 'quickly fell into place' in a positive way.

University digital systems and processes were mentioned by a quarter of the students in the sample, and $90 \%$ of these comments were initially negative, with some saying 'I couldn't figure out where I needed to enrol and who to ask' and 'The systems were very confusing, They weren't easy to understand and I'm not sure I am fully enrolled yet!' After 4 weeks though, no comments (positive or negative) were made about the digital aspects from this student group, over time. Nobody used the word 'daunting' (as had been used for friends and buildings earlier on) nor mentioned their own digital competence, the focus was more on the inaccessible systems. Perhaps this suggests that when these digital systems have been navigated, they become less important or have less of an impact over time, as they are no longer mentioned.

Tutors and others in the university were mentioned more (positively) over time; this is probably due to greater opportunities to build relationships with tutors/lecturers as the weeks progressed. 'The second thing I've had to adjust to is the teaching style as lecturers expect you to be independent outside class with revision' and 'Everything was new and unfamiliar even the first lecture was completely not understandable.' These quotes show that there were initial concerns about understanding the expectations of tutors/lecturers, however, after a few weeks; 'I've now familiarised myself with lecturers and the students in my cohort and I now feel much more at ease because I know more about them and the course' and 'Everyone in my seminars and lectures have been very welcoming and helpful by making sure that I understand the demands and what to expect during my time in university.' Again, these quotes demonstrate students' initial concerns about building relationships with significant others and how they feel more 'at ease' over time.

All of these quotes help to demonstrate that the students' initial concerns were about making new friends, getting lost, navigating the university digital processes and meeting the expectations of tutors but the good news is that their concerns were reducing over time (by the end of the semester, their views were becoming overwhelmingly positive). Much more was said over time about building relationships (with friends and tutors/lecturers) and much less about buildings and systems. Nothing was mentioned near the middle or end of the semester about the digital systems, as either an enabling or hindering factor.

These insights have implications for how we construct the student lifecycle experiences for all our students from creating positive induction experiences, to creating opportunities for them quickly to make friends and to build relationships with tutors, to supporting them to more easily navigate and access our digital systems. As previously mentioned, recent work has linked belongingness with student retention and student success (Cousin and Cureton 2012; Thomas 2012; Thomas et al. 2017). This case study supports this research by proposing that belongingness starts at induction, which in turn increases each student's likelihood of staying and succeeding. It is not primarily led by 
digital aspects; its focus is on encouraging friendship forming an engagement with others (students and tutors) first, then engagement with the university environment (predominantly buildings) and then digital platforms. Over time, these students did not mention any concerns about digital aspects. In short, this case study suggests that after the initial few weeks of understanding university digital processes e.g. enrolling, students did not see digital aspects as particularly enabling or hindering factors to their ongoing student experience.

\section{Case Study Two: The 'Third Space' Human Touch}

Recognising the importance of social justice, widening participation and a sense of belonging, the same university has taken a radical approach to supporting students through the earlier stages of transition in the creation of two hybrid roles. The role of Graduate Teaching Assistants (GTA) was created in 2014 with the emphasis placed upon teaching and student support activity rather than preparation through $\mathrm{PhD}$ for employment as an academic. The role of Academic Coaches (AC) was created in 2018 to act as personal tutors for all Foundation Year (FY) and level 4 students. At a university of opportunity located in a region with restricted graduate employability, compared to national trends, the GTA and AC roles were created for recent graduates of the university to apply for.

The GTA scheme, which is currently recruiting its 7 th iteration, has offered 120 undergraduates the opportunity to teach within the university, its partner colleges and schools, and gain a teaching qualification. Unusually for the sector, the role is a 2-year fixed term scheme paid above the regional threshold for graduate employment. The GTAs are employed on an Administrative, Professional, Technical and Clerical (APT\&C) contract and their teaching hours and student contact are closely monitored. Additionally, the GTAs are supported to undertake work placements in lifelong learning sector settings such as Further Education Colleges, Adult and Community Education, Offender Learning and Training Providers. This networking and access to alternative teaching settings acts to increase their employability, life chances and mobility. To date, all GTAs have secured graduate employability or continued to progress with further study. It is important to provide this context as the GTAs cross boundaries and offer solutions to boundary/transition 'problems' in their university role and in their transitioning role as ambassadors for the university.

Maclure's conceptualisation of transitioning/boundary crossing is useful to this discussion of boundary roles:

changes of direction need to be told, both as discontinuities (something new/ different happened here), and as accumulative events (this led from here to there). So transitions, as told, are kind of paradoxical-they are located at specific points in time and space, but they are always pulled away from the present moment to their origins in the past and their significance for the future. (Maclure 1996: 274)

The GTA scheme has not followed a linear process. In fact, its growth and success might be better articulated as accumulative and rhizomatic (Deleuze and Guattari 1987), both as insiders and outsiders, as the recent graduate GTA seeks to occupy a newly created 
role or blended role which was created to address the boundary 'problems' of the sector. Whitchurch (2013) challenges academic roles, identities and responsibilities with her concept of the 'Third Space' professional. She argues that the mass higher education system has resulted in a 'modulation of professional identities' and a 'loosening of boundaries' (2013: 3-5). Fanghanel (2012: 55) notes how the National Student Survey (NSS) (read also TEF and OfS) has 'formalized rather than diminished the divide between teachers and learners'. Simultaneously, the sector (exosystem) has been creating hybrid roles such as the GTAs which it might be argued recognise the need for unbounded student-facing professionals supporting organisational shift (mesosystem).

As Barnett identified (2005: (1), there is a nuanced relationship between an institution's research strategy and its learning and teaching strategy and cultures. The introduction of new 'shapes and spaces', such as the GTA role, may offer 'opportunities to breathe' (3) in Barnett's terms and this could in turn support the evaluation of the transitioning experience of students. Maclure (1996: 274) 'seriously - playfully' urges us to look beyond transition to transgression as looking backwards and forwards for themes may help to construct continuity narratives.

In addition, the 'third space' GTAs are a bridge to the student experience and as such may be perceived as catalysts for change and a fruitful subject for an institution to begin to understand itself and its cultures. Whitchurch recognises that the creation of hybrid student-facing roles such as GTAs and ACs is located in a boundary that allows for both playful creativity and experimentation and high risk. This boundary space between academic and professional services roles is currently poorly documented and can create misunderstandings and 'sometimes equivocation among the staff themselves about their roles and identities' (p.xiii). However, it is the ability to work within and even thrive within the tensions of this third space that offers a fascinating insight into the potential for the development of these roles.

As the GTA scheme entered its 5th iteration, the university created the Academic Coach role. Initially, this 2-year pilot employed 9 ACs in 2 of the then 4 academic faculties. All 9 ACs recruited were recent alumni of the university, 8 had been GTAs across cohorts 1-4 and 1 was an experienced Student Advisor. The pilot was created to strengthen the personal tutoring activity for all new entrants as the institution was concerned about continuation rates. The ACs are employed on an Academic Related Contract and their job description emphasises their role in coaching, guidance, support and feedback. The role evolved within the boundary space discussed earlier, was viewed as highly successful by the institution and grew into 23 permanent roles to support all new entrants (levels 3 and 4) across what then became 3 faculties. Eighteen of this group had been GTAs, a further 3 were drawn from Student Advisor roles and 1 was an FE teacher. This diverse and multi-disciplinary workforce and body of professional knowledge and experience illustrates what Whitchurch (2013: 10) describes as blended professionals.

As a group, they have multiple and layered understandings of the institution in their evolving roles as student/GTA/employee/Academic Coach, and they are actively constructing and co-constructing interface knowledge and new networks. Their role requires them to monitor the 'progress' of their tutees through 3 meetings per year. The key themes they have noted from their student interactions have been mainly focussed on managing finances, managing self at university, securing accommodation and/or dealing with homelessness, negotiating services e.g. timetabling/rooming, navigating 
cultures and expectations, making friends and feeling that they do or do not belong at university. There is also a need to discuss increasing confidence levels, reducing the sense of imposter syndrome and signposting mental health issues. Digital aspects do not feature as priority areas; perhaps as this is something they can already navigate or that they can work to navigate for themselves, whereas the more personal, relational and technical (e.g. financial and accommodation) aspects need interaction from others? In an era of increased risk of withdrawal, the creation of a sense of connectedness and belonging is crucial and the ACs strive to adopt a non-deficit personalised relationship with their tutees. Taylor and Harris-Evans (2018) categorise this approach as one which recognises the complex lives of students both outside and within the institution. By theorising transitioning as rhizomatic and multiple, students and Academic Coaches are not 'squeezed into pre-existing' linear deficit practices, instead they are engaged with the student as 'a being in the making' (Fanghanel 2012: 59).

Barnett urged the HE sector to take an ontological turn in its thinking about students and the vocabularies and positions adopted when reflecting upon student experiences. His bungee jumping motif

calls for courage on the part of the learner and a will to leap into a kind of void. There is bound to be uncertainty. A pedagogy of air...opens up spaces and calls for a will to learn on the part of the student; to learn even amid uncertainty. In the process, it is just possible that the student may come into a new mode of being. (Barnett 2007: 9)

The creation of GTAs and ACs at this HEI may be perceived as an ontological turn adopted and adapted to support becoming and belonging. Whitchurch (2013) views this opening up of multi-faceted space as useful for collaborative working and cross fertilisation. The GTAs and ACs as a cross-institutional group without boundaries are uniquely placed to support the institution to understand, 'the phenomena of failure' or, as it more often is described, 'non-completion' attending to the question 'how is it that students persist?' (Barnett 2007: 2). Ongoing work involves evaluating how the GTAs and ACs are supporting the complexity of transitions and transitioning throughout the student lifecycle. This evaluation activity recognises a changing HE landscape and community whose modulation of professional identities (Whitchurch 2013) may lead to the creation of new discourses (Barnett 2008) and expanding and proliferating identities (Clegg 2008).

\section{Conclusions}

This paper theoretically considered the areas where digitisation impacts on educators, and on students, and how this relates to students' sense of belonging within HE. The inclusion of two case studies has helped to provide an opportunity to practically answer two important questions: (1) What is important to students' developing sense of belonging in HE during their first few weeks in a university? (2) How can the differentiated human touch be provided by 'third space' professionals?

In answer to the first question, it seems clear that making friends (within the microsystem) and finding their way around the university are students' primary 
concerns. Despite the impact of the pandemic, there is no reason to think that this will change. The students who have entered into HE via the September or October 2020 intake will be just as anxious to meet their peer group and get to grips with the location of their lecture rooms, the library and the Students' Union. Navigating the systems and building relationships with the tutors (within the mesosystem) are secondarily important. Nevertheless, much of the current version of the 'new normal' in HE means that a lot of these activities are taking place on a variety of digital platforms.

Luckily, the digital related aspects were not key concerns of these students; they had other priorities. Real-time human relationships were the key concern. Perhaps digital aspects were seen as less important or created less worry as these could already be more easily navigated by students themselves. Digital aspects were not as crucial as the relationships they needed to build first, and these aspects could not be met by digital means at the time that the data was collected. In light of the pandemic, this might be different. Students may well be more open to building relationships via the digital platforms that they feel confident using; after all, the use of social networking is ubiquitous in 18-year-olds (JISC 2007). However, reports indicate that this is not enough when it comes to building online learning relationships with peers and with their teachers (HEPI 2020; Sapon-Shevin and SooHoo 2020). The majority of 2020 Freshers accept learning online for their own safety; however, it is not what they desire.

In fact, only $42 \%$ of students who took part in a recent poll, were satisfied that online learning had replaced face to face learning, whilst $33 \%$ were highly dissatisfied with this change (HEPI 2020). These students have joined HEIs across the country and moved into Halls of Residence with the aim of accessing the 'normal HE experience'. Evidence for this is offered by a HEPI poll in which just over half (54\% and 58\% respectively) of students taking part had expected to have limited access to the university facilities or to fellow students (HEPI 2020), suggesting that many students had expected to have access to their university and to interact with peers. Many students have been unhappy that they are having to self-isolate because of rising cases of campus-based Covid-19, or because the level of local or national lockdown has impacted on their ability to mix and mingle, both inside and outside of the lecture theatre. It could be argued that this is a 'form of epistemicide, the suppression of a way of knowing' (Sapon-Shevin and SooHoo 2020), that could have long-term effects on, or disrupt students developing sense of belonging. When entering the HE context, there is bound to be uncertainty (Barnett 2007), and the results we offer show that the creation of a sense of belongingness is crucial to developing more certainty within student experiences.

In answer to the second question, how can the differentiated human touch be provided by 'third space' professionals, it seems clear that GTAs and ACs have been crucial in helping to provide that much needed human contact and to be the bridge that helps to reduce the divide between student and tutor, academic, and professional services. This is even more important during the pandemic, where students are not only navigating a new physical space, and the transition into a new educational level. Students are now also attempting to navigate new virtual spaces, as well as new ways of using them as educational spaces. The paper discusses the expectations of students involving a more personalised, customised education (Cureton 2017); again, these new roles help to provide this and the much needed space to breathe (Barnett 2005). At the time of data collection, the GTA and AC feedback systems indicated that there has been little mention of digital aspects as key or primary factors of concern. However, within 
the pandemic, this has changed considerably, as owning a computer and having access to a source of stable Internet is critical to being able to access learning. This counters the belief that digital technologies offer educational quick fixes (Teräs et al. 2020). In fact, it suggests that this form of technologisation transfers the responsibility to provide solutions for political, structural and societal issues such as digital poverty, to educational providers (Labaree 2008; Simons and Masschelein 2008; Peters et al. 2019), who like the institution that we work for, are now finding ways to support students' digital access. Prior to the pandemic, digital issues may well be secondary factors but they are now top of the list of concerns for our students. Consequently, digital poverty is a key concern, and one where being able to talk to and seek support from another human being can help.

The paper shows that the human touch is crucial to student survival, retention and success. Even more so, in a time where educational delivery is primarily shared via virtual means. The postdigital definitions discussed at the start of this paper help to show that student lives are now a messy fusion of both digital and non-digital elements. The corporatised, economically focussed model of today's HE may well be pushing towards metrification and what the sector thinks the economy wants; yet, this is not necessarily what the changing postdigital student body predominantly desires or cares about. Therefore, we propose a new approach that looks beyond business as usual, to a postdigital university, where human and digital aspects interact to put the student at the centre of the university, in order to enhance their experience, and support their success.

Acknowledgements We would like to thank Professor Sarah Hayes for her support and feedback during the development of this paper.

\section{References}

Arndt, S., Asher, G., Knox, J., Ford, D. R., Hayes, S., Lăzăroiu, G., Jackson, L., Mañero Contreras, J., Buchanan, R., D’Olimpio, L., Smith, M., Suoranta, J., Pyyhtinen, O., Ryberg, T., Davidsen, J., Steketee, A., Mihăilă, R., Stewart, G., Dawson, M., Sinclair, C., \& Peters, M. A. (2019). Between the blabbering noise of individuals or the silent dialogue of many: A collective response to 'Postdigital science and education'. Postdigital Science and Education, 1(2), 446-474. https://doi.org/10.1007/s42438-019-00037-y.

Ashwin, P. (2005). Changing higher education. London: Routledge.

Baker, J. W. (2000). The 'classroom Flip': Using web course management tools to become the guide by the side. In J. A. Chambers (Ed.), Selected papers from the 11th international conference on college teaching and learning, [sponsored by] the Center for the Advancement of teaching and learning, Florida Community College at Jacksonville. Jacksonville, FL: Florida Community College at Jacksonville.

Ball, S. J. (2017). The Education Debate. Bristol: Policy Press.

Barnett, R. (2005). (Ed.). Reshaping the University. New Relationships between Research, Scholarship and Teaching. Maidenhead: Society for Research Into Higher Education and Open University Press.

Barnett, R. (2007). A will to learn: Being a student in an age of uncertainty. Berkshire: Open University Press.

Barnett, R. (2008). Critical professionalism in an age of supercomplexity. In B. Cunningham (Ed.), Exploring professionalism (education K-12) (pp. 190-208). London: University of London.

Bayne, S., \& Ross, J. (2011). 'Digital native' and 'digital immigrant' discourses. In R. Land \& S. Bayne (Eds.), Digital difference. Educational futures rethinking theory and practice (pp. 159-169). Rotterdam: Sense. https://doi.org/10.1007/978-94-6091-580-2_12.

Bolden, R., Gosling, J., O’Brien, A., Peters, K., Ryan, M., \& Haslam, A. (2012). Academic leadership Changing conceptions, identities and experiences in UK higher education. Exeter: University of Exeter, Leadership Foundation for Higher Education. 
Bosetti, L., \& Walker, K. (2009). Perspectives of UK vice-chancellors on leading universities in a knowledge-based economy. Higher Education Quarterly, 64(1), 4-21. https://doi.org/10.1111/j.1468-2273.2009.00424.x.

Boxall, M. (2016). Higher education white paper: The big changes. The Guardian, 16 May. https://www. theguardian.com/higher-education-network/2016/may/16/higher-education-white-paper-the-big-changes. Accessed 1 November 2020.

Brabazon, T. (2011). 'We've spent too much money to go Back now': credit-crunched literacy and a future for learning. E-Learning and Digital Media, 8(4), 296-314. https://doi.org/10.2304/2Felea.2011.8.4.296.

Bronfenbrenner, U. (1979). The ecology of human development. Cambridge, MA: Harvard University Press.

Brown, S. (2013). Large-scale innovation and change in UK higher education. Research in Learning Technology, 21, 1-13. https://doi.org/10.3402/rlt.v21i0.22316.

Brown, S. (2018). Identifying student need. In R. Matheson, S. Tangney, \& M. Sutcliffe (Eds.), Transition in, through and out of higher education: International case studies and best practice (pp. 17-30). Oxon: Routledge.

Callender, C., \& Thomson, J. (2018). The lost part-timers: The decline of part-time undergraduate higher education in England. London: Sutton Trust.

Chartered Management Institute (2018) 21st century leaders - Building employability through higher education. London: Chartered Management Institute. https://www.managers.org.uk/insights/research/ current-research/2018/february/21st-century-leaders. Accessed 10 October 2020.

Clegg, S. (2008). Academic identities under threat? British Educational Research Journal, 34(3), 329-345. https://doi.org/10.1080/01411920701532269.

Corver, M. (2019). Higher education is big business. WonkHE, 11 November. https://wonkhe.com/blogs/ higher-education-is-big-business/. Accessed 10 October 2020.

Cousin, G., \& Cureton, D. (2012). Disparities in student attainment (DiSA). York: Higher Education Academy. https://www.heacademy.ac.uk/system/files/projects/worlverhampton_2010_disa_final_report. pdf. Accessed 10 October 2020.

Cureton, D. (2017). The WhatWorks? Organisational change programme final report for the University of Wolverhampton. York: Higher Education Academy. https://wlv.openrepository.com/bitstream/handle/ 2436/621990/Inclusive\%20assessment\%20approaches.pdf?sequence=6\&isAllowed=y. Accessed 10 Oct 2020.

Cureton, D., \& Gravestock, P. (2019). 'We belong': differential sense of belonging and its meaning for different ethnicity groups in higher education. Compass: Journal of Learning and Teaching, 12(1). https://doi.org/10.21100/compass.v12i1.942.

Deleuze, G., \& Guattari, F. (1987). A thousand plateaus. Capitalism and schizophrenia. Minneapolis, MN: University of Minnesota Press.

Department for Business, Innovation and Skills (2016). Success as a knowledge economy: Teaching excellence, social mobility and student choice. London: Department for Business, Innovation and Skills. https://assets.publishing.service.gov.uk/government/uploads/system/uploads/attachment_data/file/ 523546/bis-16-265-success-as-a-knowledge-economy-web.pdf. Accessed 10 October 2020.

Dingli, A., \& Seychell, D. (2015). Who are the digital natives? In A. Dingli \& D. Seychell (Eds.), The new digital natives: Cutting the chord (pp. 9-22). Berlin and Heidelberg: Springer. https://doi.org/10.1007/ 978-3-662-46590-5_2.

Fanghanel, J. (2012). Being an academic. London: Routledge.

Fawns, T., Aitken, G., \& Jones, D. (2020). Ecological teaching evaluation vs the datafication of quality: Understanding education with, and around, data. Postdigital Science and Education. https://doi.org/10. 1007/s42438-020-00109-4.

Friesen, N. (2012). Report: Defining Blended Learning. https:/www.normfriesen.info/papers/Defining Blended_Learning_NF.pdf. Accessed 10 October 2020.

Gale, T., \& Parker, S. (2014). Navigating change: A typology of student transition in higher education. Studies in Higher Education, 39(5), 734-753. https://doi.org/10.1080/03075079.2012.721351.

Goodenow, C. (1993). Classroom belonging among early adolescent students: Relationships to motivation and achievement. Journal of Early Adolescence, 13(1), 21-43. https://doi.org/10.1177/ 2F0272431693013001002.

Gov. UK (2017a). Review of the teaching excellence framework year 2. London: Universities UK. http:// www.universitiesuk.ac.uk/policy-and-analysis/reports/Documents/2017/review-of-the-teachingexcellence-framework-year-2.pdf. Accessed 10 October 2020.

Gov. UK (2017b). Collection: Higher Education and Research Bill. https://www.gov.uk/government/ collections/higher-education-and-research-bill. Accessed 10 October 2020. 
Gov.UK (2018). Higher education tuition fees in England. Briefing Paper 1851. London: The House of Commons Library. https://dera.ioe.ac.uk/31330/1/CBP-8151\%20_Redacted.pdf. Accessed 10 October 2020.

Government Office for Science (2017). Future of skills and lifelong learning. London: Government Office for Science. https://assets.publishing.service.gov.uk/government/uploads/system/uploads/attachment_data/ file/727776/Foresight-future-of-skills-lifelong-learning_V8.pdf. Accessed 10 October 2020.

Gunn, A. (2018). The UK teaching excellence framework (TEF): The development of a new transparency tool. In A. Curaj, L. Deca, \& R. Pricopie (Eds.), European higher education area: The impact of past and future policies (pp. 505-526). Cham: Springer. https://doi.org/10.1007/978-3-319-77407-7_31.

Guo, X. J., Dobson, R. T., \& Petrina, S. (2008). Digital natives, digital immigrants: An analysis of age and ICT competency in teacher education. Educational Computing Research, 38(3), 235-254. https://doi.org/ 10.2190/EC.38.3.a.

HEPI (2020). Students' views on the impact of coronavirus on their higher education experience. Oxford: Higher Education Policy Institute. https://www.hepi.ac.uk/wp-content/uploads/2020/06/HEPI-PolicyNote-24_Coronavirus_FINAL.pdf. Accessed 6 November 2020.

Herodotou, C., Rienties, B., Boroowa, A., Zdrahal, Z., \& Hlosta, M. (2019). A large-scale implementation of predictive learning analytics in higher education: The teachers' role and perspective. Education Technological Research Development, 67, 1273-1306. https://doi.org/10.1007/s11423-019-09685-0.

Hunt, S., \& Boliver, V. (2019). A look at private Higher Education in the UK. InsideHigherEd, 18 April. https:/www.insidehighered.com/blogs/world-view/look-private-higher-education-uk. Accessed 10 October 2020.

Jandrić, P., Knox, J., Besley, T., Ryberg, T., Suoranta, J., \& Hayes, S. (2018). Postdigital science and education. Educational Philosophy and Theory, 50(10), 893-899. https://doi.org/10.1080/00131857. 2018.1454000.

JISC (2007). Student expectations study. London: JISC. http://www.jisc.ac.uk/media/documents/publications/ studentexpectations.pdf. Accessed 8 November 2020.

Knox, J. (2019). What does the 'Postdigital' mean for education? Three critical perspectives on the digital, with implications for educational research and practice. Postdigital Science and Education, 1(2), 357370. https://doi.org/10.1007/s42438-019-00045-y.

Labaree, D. F. (2008). The winning ways of a losing strategy: Educationalizing social problems in the United States. Educational Theory, 58(4), 447-460. https://doi.org/10.1111/j.1741-5446.2008.00299.x.

Lage, M., Platt, G., \& Treglia, M. (2000). Inverting the classroom: A gateway to creating an inclusive learning environment. The Journal of Economic Education, 31(1), 30-43. https://doi.org/10.2307/1183338.

Lewin, D., \& Lundie, D. (2016). Philosophies of digital pedagogy. Studies in Philosophy and Education, 35(3), 235-240. https://doi.org/10.1007/s11217-016-9514-7.

Maclure, M. (1996). Telling transitions: Boundary work in narratives of becoming an action researcher. British Educational Research Journal, 22(3), 273-286. https://doi.org/10.1080/0141192960220302.

Matheson, R., \& Sutcliffe, M. (2018). Developing belonging, community and creating professional identity. In R. Matheson, S. Tangney, \& M. Sutcliffe (Eds.), Transition in, through and out of higher education: International case studies and best practice (pp. 31-45). Oxon: Routledge.

Mountford-Zimdars, A., Sabri, D., Moore, J., Sanders, J., Jones, S., \& Higham, L. (2015). Causes of differences in student outcomes. Bristol: Higher Education Funding Council for England. https://dera. ioe.ac.uk/23653/1/HEFCE2015_diffout.pdf. Accessed 10 October 2020.

National College for School Leadership (2005). Leading Personalised Learning in Schools. https://dera.ioe.ac. uk/5397/1/media-578-c9-leading-personalised-learning-in-schools.pdf. Accessed 3 December 2020.

O’Donnell, V. L., Kean, M., \& Stevens, G. (2016). Student transitions in higher education: Concepts, theories and practices. York: Higher Education Academy. https://www.researchgate.net/publication/318947997 Student_transitions_in_higher_education_concepts_theories_and_practices/link/ $59877 \mathrm{~d} 74 \mathrm{a} 6 \mathrm{fdcc} 756257 \mathrm{bb} 74 /$ download. Accessed 10 October 2020.

Office for National Statistics (2018). Being 18 in 2018. Work, family, marriage - how has life changed for the children of 2000 reaching adulthood? https://www.ons.gov.uk/peoplepopulationandcommunity/ populationandmigration/populationprojections/articles/being18in2018/2018-09-13. Accessed 10 October 2020.

Office for National Statistics (2020). Labour market overview, UK: October 2020. https://www.ons.gov.uk/ employmentandlabourmarket/peopleinwork/employmentandemployeetypes/bulletins/uklabourmarket/ october2020. Accessed 10 October 2020.

Pepperell, R., \& Punt, M. (2000). The postdigital membrane: Imagination, technology and desire. Bristol: Intellect. 
Peters, M. A., \& Besley, T. (2019). Critical philosophy of the postdigital. Postdigital Science and Education, 1(1), 29-42. https://doi.org/10.1007/s42438-018-0004-9.

Peters, M. A., Jandrić, P., \& Hayes, S. (2019). The curious promise of educationalising technological unemployment: What can places of learning really do about the future of work? Educational Philosophy and Theory, 51(3), 242-254. https://doi.org/10.1080/00131857.2018.1439376.

Prensky, M. (2001). Digital natives, digital immigrants part 1. On the Horizon, 9(5), 1-6. https://doi.org/10. 1108/10748120110424816.

Sapon-Shevin, M., \& SooHoo, S. (2020). Embodied social justice pedagogy in a time of 'no touch'. Postdigital Science and Education, 2(3), 675-680. https://doi.org/10.1007/s42438-020-00177-6.

Simons, M., \& Masschelein, J. (2008). The governmentalization of learning and the assemblage of a learning apparatus. Educational Theory, 58(4), 391-415. https://doi.org/10.1111/j.1741-5446.2008.00296.x.

Sinclair, C., \& Hayes, S. (2019). Between the post and the com-post: Examining the postdigital 'work' of a prefix. Postdigital Science Education, 1(1), 119-131. https://doi.org/10.1007/s42438-018-0017-4.

Spence, C. (2019). 'Judgement' versus 'metrics' in higher education management. Higher Education, 77, 761-775. https://doi.org/10.1007/s10734-018-0300-z.

Taylor, C. A., \& Harris-Evans, J. (2018). Reconceptualising transition to higher education with Deleuze and Guattari. Studies in Higher Education, 43(7), 1254-1267. https://doi.org/10.1080/03075079.2016. 1242567.

Teräs, M., Suoranta, J., Teräs, H., \& Curcher, M. (2020). Post-Covid-19 education and education technology 'Solutionism': A Seller's market. Postdigital Science and Education, 2(3), 863-878. https://doi.org/10. 1007/s42438-020-00164-x.

Thomas, L. (2012). Building student engagement and belonging at a time of change in higher education. London: Paul Hamlyn Foundation. https:/www.heacademy.ac.uk/system/files/what_works_final_report. pdf. Accessed 10 October 2020.

Thomas, L., Hill, M., O’Mahony, J., \& Yorke, M. (2017). Supporting student success: Strategies for institutional change: What works? Student retention and success programme. Final Report. London: Paul Hamlyn Foundation. https://s3.eu-west-2.amazonaws.com/assets.creode.advancehe-documentmanager/documents/hea/private/hub/download/what_works_2_-_full_report_1568037360.pdf. Accessed 10 October 2020.

UKRI. (2019). 'Effective knowledge exchange to put universities at the heart of our country's future' Universities minister Chris Skidmore's speech to Engagement Forum, 26 September. https://webarchive. nationalarchives.gov.uk/20200504032726/https://re.ukri.org/news-opinions-events/news/effectiveknowledge-exchange-to-put-universities-at-the-heart-of-our-countrys-future-universities-minister-chrisskidmores-speech-to-engagement-forum/. Accessed 6 November 2020.

Van der Zwaan, B. (2018). Places of engagement; reflections on higher education in 2040 - a global approach. Amsterdam: University Press.

Warnes, M. (2020). Questioning the impact of teaching fellowships on excellent teachers. Postdigital Science and Education. https://oi.org/10.1007/s42438-020-00107-6.

Whitchurch, C. (2013). Reconstructing identities in higher education. The rise of the third space professionals. London: Routledge.

Williams, P. (2008). Leading schools in the digital age: A clash of cultures. School Leadership and Management, 28(3), 213-228. https://doi.org/10.1080/13632430802145779.

Williamson, B. (2017). Big data in education: The digital future of learning, policy and practice. London: Sage.

World Economic Forum. (2018). The future of jobs. Geneva: Switzerland. http://www3.weforum.org/docs/ WEF_Future_of_Jobs_2018.pdf. Accessed 10 October 2020. 